Vol 3, No. 2, Desember 2020: 734-742, DOI: https://doi.org/10.34007/jehss.v3i2.405

\title{
Efektivitas Mediasi sebagai Alternative Dispute Resolution Terhadap Perkara Perceraian di Pengadilan Agama Pematangsiantar
}

\author{
The Effectiveness of Mediation as an Alternative Dispute \\ Resolution Againts Divorce Cases at The Pematangsiantar \\ Religious Court
}

\author{
Rayani Saragih* \& Maria Ferba Editya Simanjuntak
}

Program Studi Hukum, Fakultas Sosial Dan Hukum, Universitas Quality Berastagi, Indonesia

Diterima: 17 Oktober 2020; Direview: 18 Oktober 2020; Disetujui: 28 November 2020

*Coresponding Email: $\underline{\text { rayani.saragih.sumbayak@gmail.com }}$

\section{Abstrak}

Penelitian ini bertujuan untuk menganalisis efektiiftas medisi terhadap perkara perceraian di Pengadilan Agama Pematangsiantar. Permasalahan dalam penelitian ini difokuskan pada bagaimana implementasi Mediasi pada perkara perceraian di Pengadilan Agama Pematangsintar. Metode penelitian dalam penelitian ini adalah penelitian hukum normatif empiris yaitu dengan menganalisis peraturan terkait dengan mensingkornkannya dengan hasil data yang diperoleh langsung dari Pengadilan Agama Pematangsianta, kemudian data-data tersebut dianalisis secara kualitatif. Penelitian ini menyimpulkan bahwa mediasi sebagai salah satu Alternative Dispute Resolution (ADR) dilihat sebagai cara penyelesaian sengketa yang efektif dan berkeadilan. Mediasi di luar pengadilan diatur dalam Pasal 6 Undang-Undang No. 30 Tahun 1999 tentang Arbitrase dan Alternatif Penyelesaian Sengketa. Mediasi sebagai suatu mekanisme pengambilan keputusan atau kesepakatan damai menjadi otoritas utama para pihak yang bersengketa dan menjaga hubungan baik. Mediasi wajib dilakukan terlebih dahulu dalam perkara perceraian sebelum hakim memutuskan perkara perceraian, karena setiap putusan hakim yang tidak melalui cara mediasi terlebih dahulu maka putusan dianggap batal demi hukum. Hakim Mediator semaksimal mungkin melakukan proses mediasi dengan para pihak berperkara agar tetap mempertahakn perkawinannya. Namun keberhasilan mediasi terdapat pada itikad baik kedua belah pihak dalam mengikuti dan kepatuhan pada proses mediasi.

Kata Kunci: Mediasi, Alternatif Penyelesaian Sengekta, Perceraian

\begin{abstract}
This study aims to analyze the effectiveness of meditation on divorce cases in the Pematangsiantar Religious Court. The problem in this research is focused on how to implement Mediation in divorce cases at the Pematangsintar Religious Court. The research method in this research is empirical normative legal research, namely by analyzing the related regulations by summarizing them with the results of data obtained directly from the Pematangsianta Religious Court, then the data is analyzed qualitatively. This study concludes that mediation as an Alternative Dispute Resolution (ADR) is seen as an effective and fair way of dispute resolution. Mediation outside the court is regulated in Article 6 of Law No. 30 of 1999 concerning Arbitration and Alternative Dispute Resolution. Mediation as a decision-making mechanism or a peace agreement is the main authority of the disputing parties and maintains good relations. Mediation must be carried out first in divorce cases before the judge decides in the divorce case, because every judge's decision that does not go through mediation is considered. null and void. The Mediator Judge as much as possible carries out a mediation process with the parties in the case so that the marriage is maintained. However, the success of mediation lies in the good faith of both parties in following and compliance with the mediation process.

Keywords: Mediation, Alternative Sengekta Settlement, Divorce

How to Cite: Saragih, R., \& Simanjuntak, M.F.E. (2020). Efektivitas Mediasi sebagai Alternative Dispute Resolution Terhadap Perkara Perceraian di Pengadilan Agama Pematangsiantar. Journal of Education, Humaniora and Social Sciences (JEHSS). 3 (2): 734-742.
\end{abstract}




\section{PENDAHULUAN}

Melakukan penyelesaian sengketa melalui jalur pengadilan bukan sesuatu yang buruk. Pendagilan merupakan pranata menyelesaian damai sebagai jalan dari tindakan kekerasan. Menyerahkan sengketa ke pengadlan selain memilih jalan damai juga sebaagau penilakan penyelesaian dengan menghakimi sendiri atau disebut dengan eigen richting (Antasari, 2013). Penyelesaian damai terhadap sengketa atau konflik melalui mediasi merupakan suatu hal yang diharapkan, cara ini dinili lebih baik daari penyelesaian dengan cara kekerasan atau bertanding (contenstious) karena hal seperti itu tidak memberikan nilai positif bagi mereka bahkan memberikan dampak buruk, maka dicarilah jalan keluarnya melalui jalan damai terhadap sengketa ataupun konflik yang ada.

Mediasi sebagai salah satu proses penyelesaian sengketa yang lebih cepat, murah dan juga dapat memberikan akses keadilan yang lebih besar kepada pihak-pihak dalam menemukan jelan penyelesaian sengketa yang memuaskan dan memberikan rasa keadilan. Pengintegritasan mediasi ke dalam porses beracara di pengadilan dapat menjadi salah satu instrumen yang cukup efektif dalam mengatasi maslah penumpukan perkara di pengadilan dan juga memperkuat dan memaksimalkan fungsi lembaga non-peradilan untuk penyelesaian sengketa di samping proses acara pengadilan yang bersifat ajudikatif/memutus (Hanifah, 2016).

Dalam negara hukum yang tunduk pada the rule of thw law, kedudukan peradilan diangap sebagai pelaksanaan kekuasaan kehakiman yang berperan sebagai katup penekan atas segala pelanggaran hukum dan ketertiban masyarakat. Peradilan juga dapat dimaknai sebagai tempat terakhir dalam mencari kebenaran dan keadilan, sehingga secara teoritis masih diandalkan sebagai badan yang berfungsi dan berperan menegakan kebenaran dan keadilan. Kesadaran hukum, ketaatan hukum dan efektivitas perundang-undangan adalah tiga unsur yang saling berhubungan. Sering orang mencampuradukan antara kesadaran hukum dan ketaatan hukum, padahal meskipun sangat erat hubungannnya namun tidak sama. Kedua unsur itu memang sangat menentukan efektif atau tidaknya pelaksanaan perundang-undangan di dalam masyarakat (Ali, 2012).

Mahkamah Agung telah merubah paradigma mengadili menjadi paradigma menyelesaikan sengketa/perkara hukum. Penyelesaian sengketa perkara perdata melalui litigasi mulai ditinggalkan dan beralih ke Alternative Dispute Resolution/ADR (Alternatif Penyelesian Sengketa/APS). Wujud dari perubahan ini dilakukan dengan menerbitkan PERMA No. 1 Tahun 2016 tentang Prosedur Mediasi di Pengadilan sebagaimana pengganti PERMA No. 1 Tahun 2008 tentang Prosedur Mediasi. Menurut Pasal 1 angka 10 Undang-Undang No. 30 Tahun 1999 Alternative Dispute Resolution/ADR atau alternatif penyelesaian sengketa adalah lembaga penyelesaian sengketa atau beda pendapat mealui prosedur yang disepakati para pihhak, yaitu penyelesaian di luar pengadilan dengan cara konsultasi, negosiasi, mediasi, konsolidasi atau penilaian ahli. Mediasi merupakan cara penyelesaian sengketa mealuli proses perundingan untuk memperoleh kesepakatan para pihak dengan dibantu oleh mediator.

Pengadilan sebagai salah satu instrumen penegak hukum telah melaksanakan mediasi sejak 2008. Namun keberhasilan mediasi masih dibawah harapan Hal ini menunjukkan bahwa integrasi mediasi dalam sistem beracara di pengadilan belum efektif. Efektivitas mediasi tidak sepenuhnya tergantung kepada pelaksana penegak hukum. Langkah pemerintah Indonesia ini berkiblat pada negara-negara maju yang telah berhasil menyelesaikan sengketa melalui mediasi, seperti Jepang, Singapura, Amerika Serikat, Canada, Belanda dan Australia (Saifullah, 2015).

Menurut Lawrence M. Friedman, bahwa sistem hukum dapat berjalan baik jika tiga elemen sistem hukum saling mendukung, yaitu penegak hukum, aturan hukum dan budaya hukum. Penegak hukum dapat bekerja dengan baik jika aturan hukumnya baik dan jelas, serta masyarakat patuh kepada hukum. Jika ketiga elemen tidak saling mendukung maka penegakkan hukum (law enforcement) menjadi tidak efektif . Tingkat perceraian semakin meningkat dari tahun ketahun baik sejak diterbitkannya Perma No. 1 tahun 2008. Tentu ini membuktikan proses mediasi yang belum maksimal mampu mencegah perceraian. 
Kurangnya mediator professional yang bersertifikat disetiap pengadilan salah satu penyebab tidak maksimalnya mediasi. Masih banyak mediator yang tersedia adalah hakim yang merangkap seklaigus menjadi mediator sehingga tidak efektif dan efesien dalam bermediasi. Disamping itu tentu penyebab dan konflik-konflik yang memciu terjadinya perceraian yang tidak dapat diselesaikan dengan cara berdamai lagi sehingga harus berakhir berpisah/bercerai.

Putusnya perkawinan karena perceraian adalah putusnya ikatan perkawin-an antara suami dan isteri dengan keputusan pengadian melalui pemeriksaan di depan sidang pengadilan dan ada cukup alasan bahwa di antara suami istri tidak dapat hidup rukun lagi sebagai suami-isteri (Subekti, 2010). Pada dasarnya melakukan perkiwanan itu adalah bertujuan untuk selamalamanya, tetapi adakalanya ada sebab-sebab tertenu yang mengakibatkan perkawinan tidak dapat diteruskan jadi harus diputuskan di tengah jalan atau terpaksa diputus dengan sendirinya atau dengan kata lain terjadi perceraian antara suami-isteri. Perkara perceraian termasuk perkara yang contentius yaitu suatau perkara yang di dalamnya berhadapan kedua belah pihak yang bersengketa, disebut juga dengan perkara gugatan dan termasuk karakteristik sengketa emosional (Purnamasari, 2017).

Menurut Pasal 1 Undang-Undang No. 1 Tahun 1974 Tentang Perkawinan, "perkawinan ialah ikatan lahir batin antara seorang pria dengan seorang wanita sebagai suami istri dengan tujuan membenuk keluarga (rumah tangga), yang bahagia dan kekal berdasarkan Ketuhanan Yang Maha Esa." Pasal 2 ayat (1) mentukan bahwa "perkawinan adalah sah, apabila dilakukan menurut hukum masing-masing agamanya dan kepercayaannya itu." Sedangkan dalam Pasal 2 ayat (2) tersebut mennetukan bahwa, "tiap-tiap perkawinan dicatat menurut peraturan perundang-undangan yang berlaku."Menurut Hukum Islam, kata perkawinan sama asrtinya dengan kata nikah. Nikah menurut bahasa mempunyai arti yang sebenarnya yakni dham yang berarti menghimpit, menindih, atau berkumpul. Nikah mempunyai arti kiasan yakni wathaa yang berarti setubuh atau aqad yang berarti perjanjian pernikahan (Syarifuddin, 2014).

\section{METODE PENELITIAN}

Metode penelitian hukum normatif empiris ini pada dasarnya merupakan penggabungan antara pendekatan hukum normatif dengan adanya penambahan berbagai unsur empiris. Penelitian ini dilakukan dengan menganalisis perkara perceraian secara yuridis pada peraturan perundang-undangan yang berkaitan dengan penegakan hukum dan penyelesaian sengketa secara damai (mediasi) serta mengaitkannya dengan kasus yang ada, kemudian akan diformulasikan dengan mekanisme proses persidangan di lingkungan PA Pematangsiantar terkait.

Metode penelititan di sini menggunakan metode penelitian kualitatif. Penelitian kualitatif adalah suatu penelitian ilmiah yang bertujuan untuk memahami suatu fenomena dalam kasus sosial secara alamiah dengan mengedepankan proses interaksi komunikasi yang mendalam antara peneliti dengan fenomena yang diteliti (Herdiansyah, 2010).

Sumber data yang digunakan dalam penelitian ini adalah data sekunder, yaitu bahan hukum primer, bahan hukum sekunder maupun hukum tersier (Soekanto, 2013). Bahan hukum primer merupakan bahan pokok data utama yang diperoleh dari PA Pematangsiantar dengan melakukan wawancara secara langsung. Undang-Undang No. 1 Tahun 1974 tentang Perkawinan, PERMA No. 1 Tahun 2016 tentang Prosedur Mediasi di Pengadilan sebagaimana pengganti PERMA No. 1 Tahun 2008 tentang Prosedur Mediasi. Undang-Undang No. 30 Tahun 1999 tentang Arbitrase dan Alternatif Penyelesaian Sengketa, dan peraturan perundang-undangan lainnya yang berkaitan dan relevan dengan penelitian ini.

Bahan hukum sekunder merupakan bahan hukum yang dapat memberikan penjelasan mengenai bahan hukum primer. Dalam penelitian ini bahan hukum sekunder yang digunakan seperti buku, jurnal. Bahan hukum tertier, merupakan bahan hukum yang memberikan petunjuk maupun penjelasan terhadap bahan hukum primer dan bahan hukum sekunder. Dalam penelitian ini bahan hukum tersier yang digunakan seperti Kamus Hukum, Kamus InggrisIndonesia, Kamus Besar Bahasa Indonesia, dan sebagainya. Tekhnik pengumpulan data data dalam penelitian ini berupa wawancara dan studi dokumen pada Hakim dan bagian terkait pada PA Pematangsiantar . http://mahesainstitute.web.id/ojs2/index.php/jehss

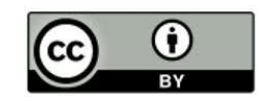




\section{HASIL DAN PEMBAHASAN}

\section{Implementasi Mediasi Dalam Perkara Perceraian di PA Kota Pematangsiantar}

Pengadilan Agama Kota Pematangsiantar sebagai lembaga pengadilan telah menjalankan dan melaksanakan mediasi berdasarkan amanat Perma No. 1 Tahun 2008 tentang Prosedur Mediasi sebagaimana telah diubah dalam Perma No. 1 Tahun 2016. PA Pematangsiantar dalam menangani dan menyelesaikan perkara perceraian selalu mengutamakan prnsip-prinsip dalam Undang-Undang No. 1 Tahun 1974 tentang Perkawinan. Para Hakim Mediator selalu berupaya semaksimal mungkin melakukan mediasi kepada para pihak yang berperkara untuk sama-sama mempertahankan perkawinannya dengan berbagai pertimbangan-pertimbangan.

Mediasi wajib dilaksanakan dalam penyelesiaan perkara perceraian karena salah satu prosedur penyelesaian sengketa dan juga merupakan bagian dari Hukum Acara yang harus dilalui oleh para pihak sebagaimana ketentuan Pasal 3 Perma No, 1 Tahun 2016 yang menyatakan bahwa "Setiap Hakim Mediator, Para Pihak/kuasa hukum wajib mengikuti prosedur penyelesaian sengketa melalui Mediasi." Semua sengketa perdata yang diajukan ke Pengadilan termasuk perkara perlawanan (verzet) atas putusan verstek dan perlawanan pihak pihak berperkara (partij verzet) maupun pihak ketiga (derden verzet) terhadap pelaksanaan putusan yang telah berkekuatan hukum tetap,wajib terlebih dahulu diupayakan penyelesaian melalui mediasi, kecuali ditentukan lain berdasarkan Perma No. 1 Tahun 2016 (Mahkamah Agung, 2016).

Mediasi juga merupakan bagian dari Hukum Aacara yang harus dilalui oleh para pihak dalam menyelesaikan sengketa diantara mereka. Selain itu mediasi sebagai instrumen untuk meningkatakan akses masyarakat terhadap keadilan sekaligus implementasi asas penyelenggaraan peradilan yang sederhana, cepat dan biaya ringan (Wahyudi, 2020).

Menurut (Wahyudi, 2020) mediasi merupakan salah satu cara penyelesaian sengketa melalui proses perundingan untuk mencapai kesepakatan dengan dibantu oleh Mediator yang bertujuan untuk menyelesaikan sengketa antara para pihak yang sifatnya netral dan imparsial. Mediasi bermanfaat untuk mempercepat proses penyelesaian sengketa, memperlancar jalur keadilan (access to justice) bagi masyarakat serta meminimalisir biaya.

\section{Prosedur Mediasi di PA Pematangsiantar}

Dalam penyelesaian perkara secara damai dalam sistem peradilan (court annexed mediation) atau yang sering disebut dengan court annexed dispute resolution yang sudah lama dikenal (Rahmawati, 2016). Pengintegritasan mediasi dalam proses litigasi di pengadilan bukan tanpa alasan yang jelas, nmaun sebagai bentuk alternatif penyelesaian sengketa mediasi memberikan berbagai keuntungan, diantaranya ialah: a) mewujudkan kesepakatan damai yang permanen; b) menempatkan kedua belah pihak pada posisi yang sama; c) proses yang cepat, sederhana dan biaya ringan; d) bersifat informal; e) pihak sendiri berupaya menyelesaikan sendiri persoalannya; f) tidak perlu aturan pembuktian; g) hasil yang dituju adalah sama-sama menang (win-win solution) (M. Yahya, 2010). Proses mediasi yang dilakukan PA Pematangsiantar sesuai dengan skema prosedur mediasi berdasarkan Perma No. 1 Tahun 2016 berikut : 


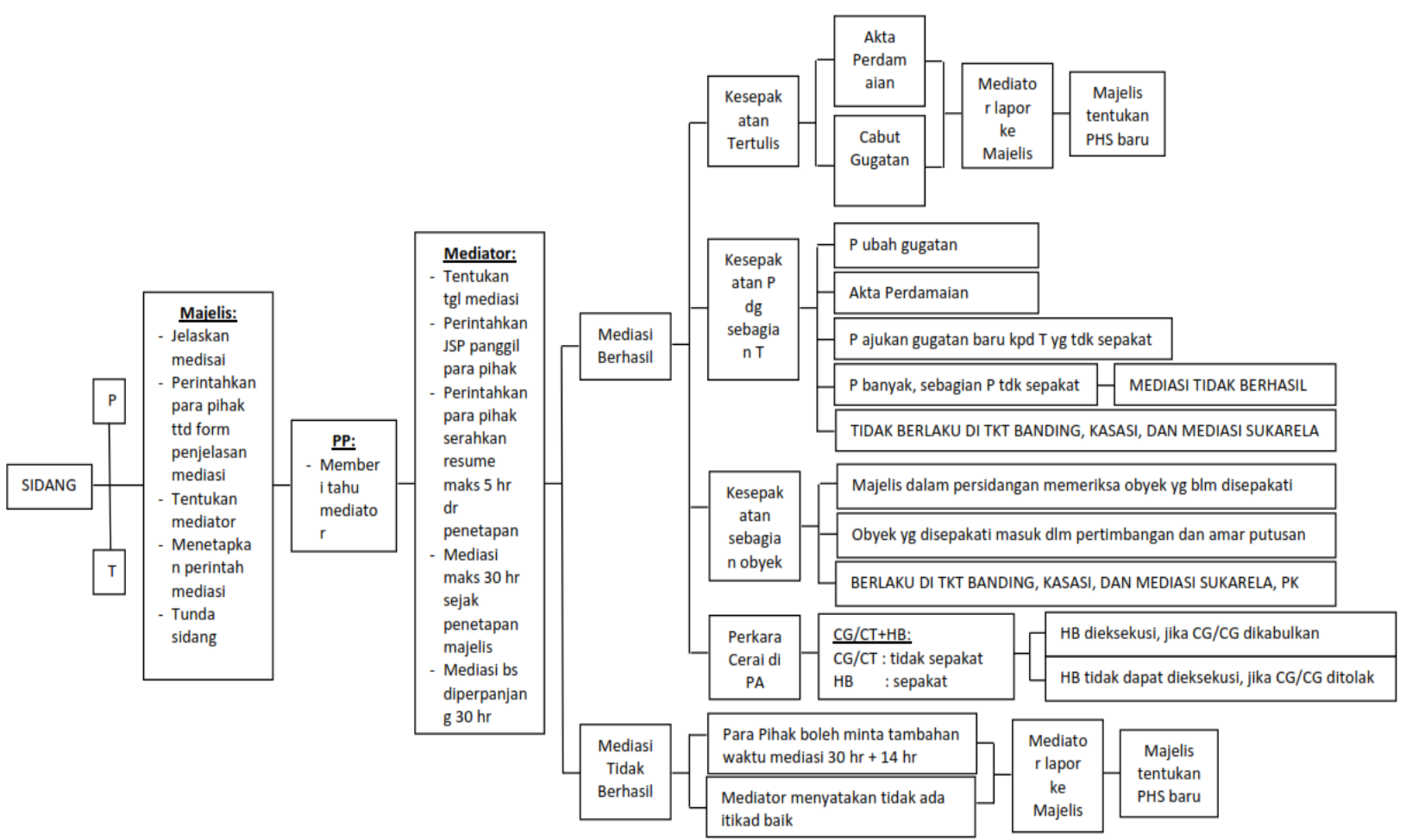

\section{Gambar 1. Skema Prosedur Mediasi}

Proses mediasi berlangsung paling lama 30 (tiga puluh) hari terhitung sejak penetapan perintah melakukan mediasi. Mediator ialah Hakim atau pihak lain yang memiliki Sertifikat Mediator sebagai pihak netral yang membantu para pihak dalam proses perundingan guna mencari berbagai kemungkinan penyelesaian sengketa tanpa menggunakan cara memutus atau memaksakan sebuah penyelesaian. Proses mediasi pada dasarnya bersifat tertutup kecuali para pihak berkehendak lain. Namun penyampaian laporan Mediator mengenai pihak yang tidak beretikad baik dan ketidakstabilan proses Mediasi kepada Hakim pemeriksa perkara bukan merupakan pelanggaran terhadap sifat tertutup mediasi.

Para pihak wajib menghadiri secara langsung pertemuann mediasi dengan atau tanpa didampingi oleh kuasa hukum, kecuali ada alasann saah seperti kondisi kesehatan yang tidak memungkinkan hadir dalam pertemuan mediasi berdasarkan surat keterangan dokter, di bawah pengampuan, berkediaman/berkedudukan di luar negeri atau menjalankan tugas negara atau pekerjaan yang tidak dapat ditinggalkan. Mediasi diselenggarakan di ruang Mediasi Pengadilan atau di tempat lain di luar Pengadilan yang disepakati oleh para pihak.

Para pihak dan/atau kuasa hukumnya wajib menempuh Mediasi dengan itikad baik dalam proses mediasi dan akibat hukum para pihak yang tidak beritikad baik falam proses mediasi. Thalis menjelaskan, apabila penggugat dinyatakan tidak beritikad baik dalam proses mediasi sebagaimana dimaksud dalam Pasal 7 ayat (2) Perma No. 1 Tahun 2016 maka berdasarkan Pasal 23 gugatan dinyatakan tidak dapat diterima oleh Hakim pemeriksa perkara. Hal ini ditegaskan dalam Pasal 22 Perma No. 1 Tahun 2016 (Hukum Online, 2016). Langkah-langkah yang ditempuh mediator dalam melakukan mediasi ialah sebgai berikut (Dauly, 2020) :

1. Diawali dengan tahap perkenalan antara mediator dan para pihak yang bercerai;

2. Melakukan identifikasi masalah dan kepentinngan antara kedua belah pihak yang berperkara;

3. Menggali opsi dalam mencari solusi atas permasalahan yang dihadapi kedua belah pihak;

4. Merumuskan kesepakatan damai (hasil mediasi);

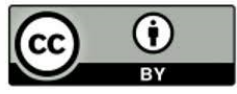


5. Penandatangan kesepakatan damai dan dibaut dalam akta perdamaian.

\section{Efektivitas Keberhasilan Mediasi Pada Perkara Perceraian di PA Pematangsiantar}

Mediasi sebagai pilihan alternatif penyelesaian sengketa yang dapat memberikan keadilan perdamaian bagi para pihak yang bersengketa tanpa ada menang kalah karena tujuan mediasi itu perdamaian (Dauly, 2020). Secara penegakan hukum PA Pematangsiantar telah efektif dalam menjalankan proses mediasi. Namun keberhasilan suatu mediasi tidak dapat hanya dilihat dari sisi penegakan hukum atau lembaga pengadilannya. Namun, para pihak yang berperkarag unsur terpenting dalam keberhasilan mediasi tersebut. Keberhasilan mediasi dapat tercapai apabila para pihak yang berperkara memiliki itikad baik dalam proses mediasi dan bersepakat untuk berdamai.

Perceraian merupakan salah satu jenis perkara yang paling banyak masuk di PA Pematangsiantar, hal ini dapat dibuktikan berdasarkan salah satu laporan tahunan PA Pematangsiantar berikut (Pengadilan Agama Pematangsiantar, 2018) :

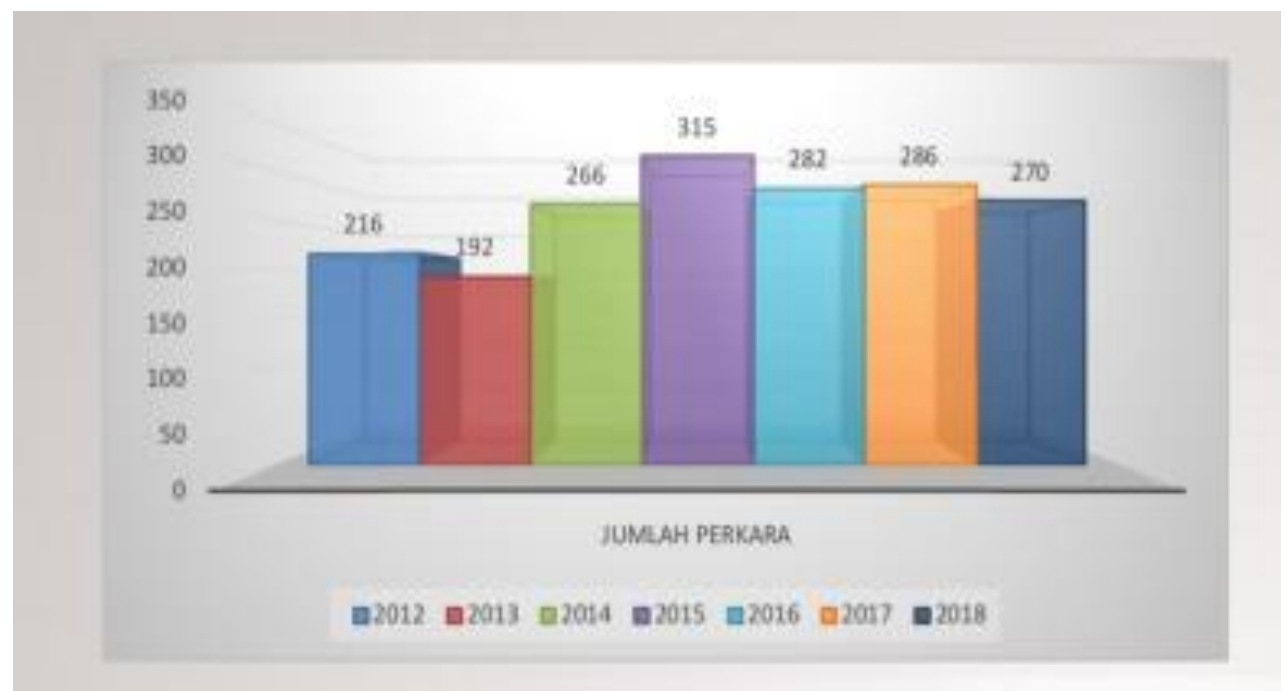

Gambar 2. Grafik Perkara di PA Pematangsiantar

TAHUN

2012

2013

2014

2015

2016

2017

2018
JUMLAH PERKARA

216

192

266

315

282

286

270

Tabel 1. Grafik Perkara di PA Pematangsiantar 


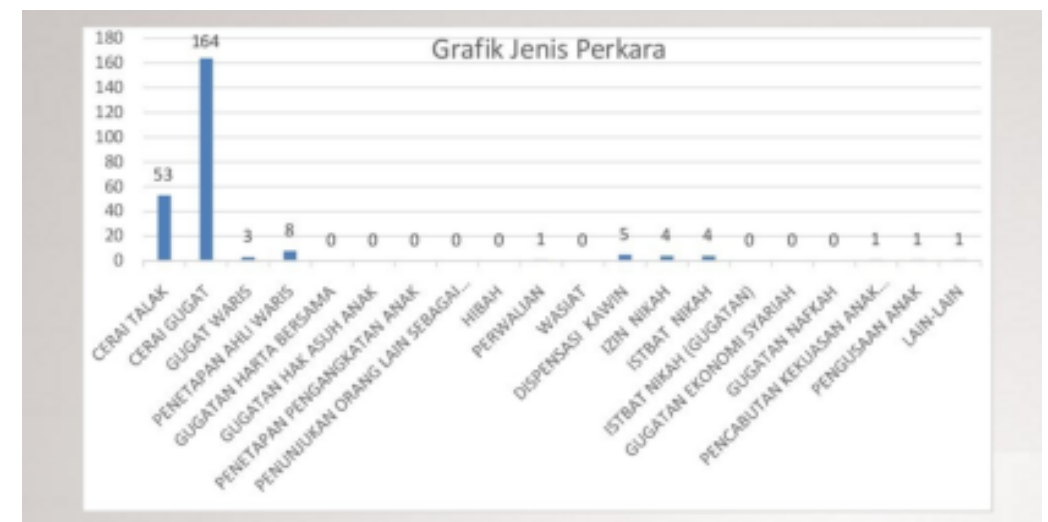

Gambar 3. Grafik Jenis Perkara

\begin{tabular}{|c|c|c|}
\hline No. & Jenis Perkara & Jumlah Diterima \\
\hline 1 & Cerai Talak & 53 \\
\hline 2 & Cerai Gugat & 164 \\
\hline 3 & Gugat Waris & 3 \\
\hline 4 & Penetapan Ahli Waris & 8 \\
\hline 5 & Gugatan Harata Bersama & - \\
\hline 6 & Gugatan Hak Asuh Anak & - \\
\hline 7 & Penetapan Pengangkatan Anak & - \\
\hline 8 & Penunjukan Orang Lain Sebagai Wali & - \\
\hline 9 & Hibah & - \\
\hline 10 & Perwalian & 1 \\
\hline 11 & Wasiat & - \\
\hline 12 & Dispensasi Kawin & 5 \\
\hline 13 & Izin Nikah & 4 \\
\hline 14 & Istbat Nikah & 4 \\
\hline 15 & Istbat Nikah (gugatan) & - \\
\hline 16 & Gugatan Ekonomi Syari'ah & - \\
\hline 17 & Gugatan Nafkah & - \\
\hline 18 & Pencabutan Kekuasaan Anak Dari Orang Tua & 1 \\
\hline 19 & Penguasaan Anak & 1 \\
\hline 20 & Lain-Lain & 1 \\
\hline \multicolumn{2}{|r|}{ Jumlah } & 245 \\
\hline
\end{tabular}

\section{Tabel 2. Jumlah Jenis Perkara}

Berdasarkan grafik dan jumlah perkara tersebut di atas dapat dilihat dan disimpulkan bahwa persentase perkara perceraian lebih banyak baik cerai gugut mauapun cerai talak dibandingan dengan perkara lainnya. Hal ini menunjukan tingkat perceraian di PA Pematangsiantar cukup tinggi. PA Pematangsiantar telah berupaya semaksimal mungkin memediasi para pihak yang beperkara untuk berdamai agar tetap mempertahankan pernikahan para pihak. Namun, kesepakatan damai tersebut tidak mudah dilakukan apabila pihak yang berperkara bersikeras untuk bercerai dengan alasan-alasan yang beraneka ragam. Adapun beberapa faktor yang memnjadi hambatan tidak berhasilnya mediasi diantaranya ialah (Dauly, 2020) (Wahyudi, 2020):

1. Tidak adanya itikad baik dari pihak yang beperkara dalam melaksanakan mediasi, tidak hadirnya para pihak secara berturut-turut;

2. Anggapan para pihak yang berperkara yang masih menganggap bahwa setiap sengketa perdata diajukan ke Pengadilan tidak akan mencapai kesepakatan perdamaian; 
3. Para pihak yang berperkara telah sepakat berpisah;

4. Kurangnya pengethauan para pihak yang berperkara terkait mediasi;

5. Kurangnya sosialisasi mengenai kemanfaatan dan prosedur mediasi;

6. Kuasa hukum yang masih kurangnya peran untuk mendukung proses mediasi serta kurangnya keterlibatan dalam proses mediasi;

7. Mediator sebaiknya perlu menampilkan seikap positif dan antusias dalam menjalankan mediasi.

PA Pemtangsiantar berupaya dalam mengatasi hambatan-hambatan tidak berhasilnya mediasi tersebut ialah dengan tetap memberikan penejlasan tentang pentingnya mediasi sebagai akses kepada masyarakat tehadap keadilan (access to justice), PA Pematangsiantar memiliki Hakim-Hakim yang telah mengikuti dan dinyatakan lulus pelatihan Mediator dan memiliki sertifikat.

Sedangkan faktor penyebab terjdinya perceraian diantaranya ialah mabuk dan madat, ekonomi, meninggalkan salah satu pihak, kekejaman jasmani dan mental, dihukum penjara akibat berbuat kriminal, narkoba dan tidak ada keharmonisan. Tidak adanya keharmonisan ini menjadi penyebab yang paling banyak dan sering terjadi pada perkara perceraian di PA Pematangsiantar pada tahun terkahir.

Keberhasilan atau kegagalan mediasi sangat dipengaruhi faktor-faktor pendukung dan penghambat selama proses mediasi. Adapun yang menjadi faktor pendukung keberhasilan mediasi yaitu: a) kemampuan mediator, kegigihan mediator untuk merealisasikan keberhasilan mediasi dan kemampuan atau skill penguasaan mediator terhadap tekhnis mediasi; b) faktor sosiologis dan psikologis yang bergantung pada rasa ketidaknyamanan; c) moral dan kerohanian; d) itikad baik para pihak, itikad baik untuk menghadiri sengketa melalui medaisi dan para pihak memiliki kesadaran untuk berdamai dan menyadari kekeliruannya. Sedangkan faktor penghambat keberhasila mediasi ialah keinginan kuat untuk bercerai, sudah terjadi konflik yang berkepanjangan dan faktor psikologi aatau kejiwaan.

\section{SIMPULAN}

Dalam melaksanakan tugas dan fungsinya PA Pematangsiantar telah melakukan proses mediasi berdasarkan PERMA No. 1 Tahun 2016. Tingkat kepatuhan/itikad baik dari para pihak yang berperkara dalam menajalankan proses mediasi masih rendah dan keinginan kuat para pihak untuk bercerai. Efektivitas keberhasilan mediasi pada perkara perceraian di PA Pematangsiantar menunjukan bahwa mediasi ada yang berhasil dan ada yang gagal, hal ini dipengaruhi oleh berbagai faktor penyebab perceraian dan hambatan-hambatan yang terjadi.

\section{UCAPAN TERIMA KASIH}

Terima kasih penulisan ucapkan kepada Direktorat Riset dan Pengabdian Masyarakat (DRPM) kementrian riset dan tekhnologi dengan Kontrak Nomor 256/LL1/PG/2020. Terima kasih kepada Pengadilan Agama Kota Pematangsiantar yang telah berkontribusi membantu dalam pelaksanaan penelitian ini.

\section{DAFTAR PUSTAKA}

Antasari, R. (2013). Pelaksanaan Mediasi dalam Sistem Peradilan Agama. Jurnal Intizar, 19(1): 45-70

Dauly, M. T. (2020). Mediasi. (H. P. Agama, Interviewer) Pematangsiantar, Sumatera Utara, Indonesia.

Hanifah, M. (2016). Kajian Yuridis Mediasi Sebagai Alternatif Penyelesaian Sengketa Perdata di Pengadilan. Jurnal Hukum Acara Perdata, 2(1): 43-34

Herdiansyah, H. (2010). Metodologi Penelitian Kualitatif Untuk Ilmu-Ilmu Sosial. Jakarta: Salemba Humanika. Heryani, A.A.W.. (2012). Menjelajahi Kajian Empiris Terhadap Hukum. Jakarta: Kencana

Hukum Online. (2016). Point Penting yang Diatur dalam Perma No. 1 Tahun 2016. Retrieved Agustus 2020, from www.hukumonline.com: https://www.hukumonline.com/berita/baca/lt56bb2d4541fd5/inipoin-penting-yang-diatur-dalam-perma-no1-tahun-2016/

M. Yahya Harahap. (2010), Hukum Acara Perdata. Jakarta: Sinar Grafika

$\underset{w w w}{\stackrel{w}{W} h t t p: / / m a h e s a i n s t i t u t e . w e b . i d / o j s 2 / i n d e x . p h p / j e h s s}$

Mmahesainstitut@gmail.com

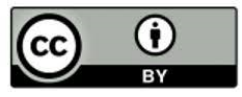

This work is licensed under a Creative Commons Attribution 4. 
Pengadilan Agama Pematangsiantar. (2018). Laporan Tahunan. Retrieved Agustus Selasa, 2020, from papematangsiantar: https://pa-pematangsiantar.go.id/index.php/informasi-umum/laporan-tahunan

Purnamasari, F. (2017). Pelaksanaan Mediasi Pada Penyelesaian Perceraian Di Pengadilan Agama Kuningan. Jurnal Unifikasi, 4(2): 15-25.

Rahmawati, E.S. (2016). Implikasi Mediasi Bagi Para Pihak Yang Berperkara di Pengadilan Agama Malang. Jurnal Hukum dan Syari,ah, Vol. 8 No. 1

Saifullah, M. (2015). Mediasi dalam Penyelesaian Perkara Perceraian. AL-Ahkam, 24(2): 35-55.

Soekanto, S. (2013). Penelitian Hukum Normatif Suatu Tinjauan Singkat (15 ed.). Jakarta: Raja Grafindo Persada.

Subekti, T. (2010). Hukum Keluarga Dan Perkawinan. Purwokerto: Universitas Jenderal Soedirman.

Syarifuddin, A. (2014). Hukum Perkawinan Islam di Indonesia. Jakarta: Kencana Prenadamedia.

Wahyudi, M. R. (2020). Mediasi Di Pengadilan Agama Kota Pematangsiantar. (Hakim, Interviewer) Pematangsiantar, Sumatera Utara, Indonesia.

\section{Perundang-undangan}

Undang-Undang No. 30 Tahun 1999 Tentanf Arbitrase (Alternative Dispute Resolution/ADR)

Undang-Undang No. 1 Tahun 1974 Tentang Perkawinan

Peraturan Mahkamah Agung No. 1 Tahun 2016 tentang Prosedur Mediasi di Pengadilan sebagaimana pengganti Peraturan Mahkamah Agung No. 1 Tahun 2008 tentang Prosedur Mediasi

Peraturan Mahkamah Agung No. 1 Tahun 2008 Tentang Prosedur Mediasi 